\title{
Weapons of war scoop spoof Nobels
}

It was a case of 'make love not war' winning out over 'don't ask, don't tell'. Borrowing a bad story line from a B movie, researchers at the US Air Force Research Laboratory at the Wright-Patterson Air Force base in Ohio proposed to develop chemical aphrodisiacs that would make enemy soldiers sexually irresistible to each other. The idea - dubbed the 'gay bomb' - earned the unnamed Ohio scientists the 2007 Ig Nobel Peace Prize, which was awarded at Harvard University on 4 October along with nine other prizes.

The competition for the Peace Prize was intense even within Wright-Patterson laboratory itself. Researchers there also proposed chemicals designed to attract stinging and biting creatures, as well as low-toxicity compounds that would "create severe and lasting halitosis" for those exposed to tiny concentrations. Despite the merits of the competing concepts, none had quite the 'legs', so to speak, of the gay bomb.

The Ig Nobels - a spoof of the real Nobel prizes (see page 642) - have been awarded annually since 1991 . But the gay bomb would never have basked in their glow had it not been for the Sunshine Project in Austin, Texas. The group's director Edward Hammond caught wind of the report when he saw a promotional CD-ROM of 'non-lethal weapons', prompting him to seek all supporting documents under the Freedom of Information Act.

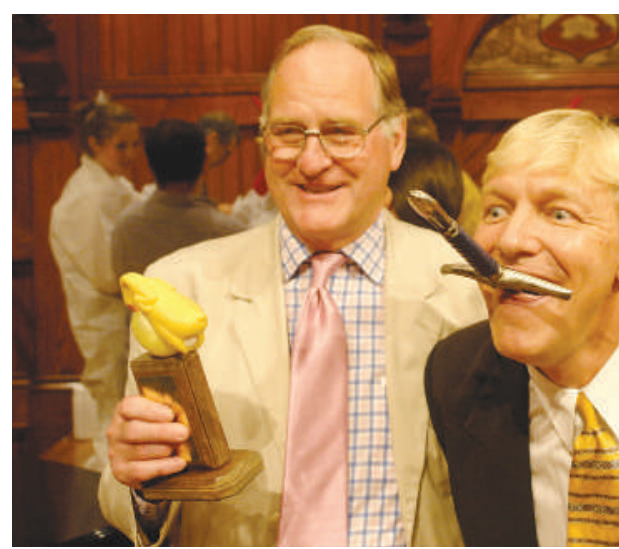

The fate of the gay bomb project is unclear, says Ig Nobel impresario Marc Abrahams, who was told by former lab staff that "if research on the gay bomb had proceeded further, it would have immediately been stamped secret, and neither you nor I would have any way of knowing about it." Fortunately, however, the Ig Nobel selection committee was lucky enough to hear about the idea, as well as others that warranted similar distinction.

The Linguistics Prize, for example, went to researchers from the University of Barcelona in Spain for showing that rats cannot always distinguish between a person speaking Japanese backwards and a person speaking Dutch backwards.
This year's Ig Nobel prize for medicine went to Brian Witcombe (left) and Dan Meyer for their finding that sword-swallowing can damage your health.

\section{Panel issues warning over mineral market tremors}

The United States should establish an agency to track markets for minerals that are critical components of industrial products, says a panel of the National Academies.

In a report published on 5 October, the panel says that the existing Minerals Resources Program at the US Geological Survey in Reston, Virginia, does not have the resources, authority or autonomy needed to track the supply and demand of valuable minerals used in everything from televisions to cars. It cites the Energy Information Administration (EIA) - set up in Washington DC in the wake of the 1973 oil shock - as a model for a future federal agency.

"We need quality information to be able to assess the vulnerability to disruption," says Roderick Eggert, chair of the panel and a mineral economist at the Colorado School of Mines in Golden.

The report points out that the sharp fluctuations in mineral prices and the minerals' varied uses receive little public attention. Engineers have folded obscure minerals from all over the periodic table into

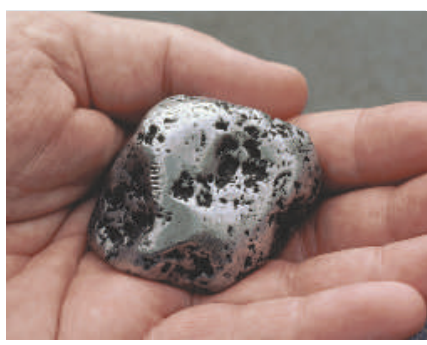

Platinum supplies are at risk. high-tech alloys, films and catalysts that industry relies on, it notes.

And mineral markets have been rocked by wild price swings: in late 2002, for example, the price of indium - used in flat-panel displays - hit a historic low of $\$ 60$ per kilogram. In 2005, the price reached $\$ 1,000$ per kilogram (see Nature 449, 131; 2007).

Booming demand for minerals in India and China suggests that historical trends might be an unreliable guide for the next few decades, says Thomas Graedel, another of the report's authors and an industrial ecologist at Yale University in Connecticut.

The report identifies indium, manganese, niobium, platinumgroup metals and rare-earth metals as the important minerals whose supply is most in doubt. The Minerals Resources Program has only 135 staff, compared with 350 at the EIA. Unlike the EIA, it has no legislative authority to demand market information from industrial companies and no right to publish data independently of its parent agency.

But Jerry Taylor of the Cato Institute, a pro-free-market thinktank based in Washington DC, says that replicating the EIA - which he brands a "subsidy to the oil industry" - is unnecessary. Prices already provide incentives for companies to pay for and gather mineral data, he says, and the risks of supply shocks are already factored into prices. Eric Hand 